\title{
CONSUMER PREFERENCES FOR RED WINE IN THE SPANISH MARKET
}

\section{PREFERÊNCIAS DO CONSUMIDOR DE VINHO TINTO NO MERCADO ESPANHOL}

\author{
Rodolfo Bernabéu ${ }^{1 *}$, Mónica Díaz ${ }^{2}$, Fátima Oliveira ${ }^{3}$ \\ ${ }^{1}$ Escuela Técnica Superior de Ingenieros Agrónomos y de Montes, Universidad de Castilla-La Mancha, Campus Universitario s/n, 02071 \\ Albacete. Spain. \\ ${ }^{2}$ Escuela de Ingenieros Agrónomos, Universidad de Castilla-La Mancha, Ronda de Calatrava s/n, 13003 Ciudad Real. Spain. \\ ${ }^{3}$ Escola Superior Agrária de Coimbra, Instituto Politécnico de Coimbra, Estr. Bencanta, 3045-601 Coimbra. Portugal.
}

*corresponding author: Tel.: +34967599200, Fax: +34967599238, e-mail: rodolfo.bernabeu@uclm.es

(Received 16.02.2016. Accepted 19.12.2016)

\section{SUMMARY}

Consumers are the core of wine marketing. Identifying their preferences, socioeconomic characteristics and behaviour is a key to designing actions for the wine sector which result in marketing opportunities for wine companies. To answer these questions 800 personal surveys were taken of wine consumers in Madrid and Barcelona. These two cities are characterized as large consumption and business centres and showcases for wine promotion in Spain. The conjoint analysis technique was used to identify wine consumers' preferences and for their characterization, we used socioeconomic analysis and the identification of their ethnocentric tendencies (CETSCALE). The results show that the most highly-valued elements are price and type of wine, in that order. Consumers prefer wine which offers a good price-quality ratio. The origin of the wine does not seem to be an especially important element although wine consumers from Barcelona present more ethnocentric behaviour than those from Madrid, tending to consume wines produced in their own region.

\section{RESUMO}

Os consumidores são o pilar da comercialização dos vinhos. Identificar as suas preferências, o comportamento e as suas características socioeconômicas é fundamental para projetar ações de marketing, que originam oportunidades de mercado para as empresas de vinho. Para responder a estas perguntas foram realizados 800 inquéritos a consumidores de vinho em Madrid e Barcelona. Estas duas cidades são caracterizadas por serem importantes centros de consumo, centros de negócios e de serem ainda as principais vitrinas para a promoção do vinho em Espanha. Para detetar as preferências dos consumidores de vinho foi aplicada a técnica de análise conjunta e para a sua caracterização a análise socioeconómica e identificação de tendências etnocêntricas dos consumidores (CETSCALE). Os resultados demonstram que os atributos mais valorizados são em primeiro o preço seguido pelo tipo de vinho. Os consumidores preferem o vinho que oferece uma boa relação qualidade/preço. $\mathrm{O}$ atributo origem não parece ser um elemento especialmente importante, embora os consumidores de vinho de Barcelona apresentem comportamento mais etnocêntrico do que os de Madrid, através da preferência do consumo de vinhos produzidos na própria região.

Key words: consumer behaviour, conjoint analysis, CETSCALE, wine marketing.

Palavras-chave: comportamento do consumidor, análise conjunta, CETSCALE, marketing de vinhos.

\section{INTRODUCTION}

In recent years, wine consumption in Spain has fallen steadily, and to make matters worse, the fall in consumption is expected to continue (Ikerfel-OeMV, 2012).

Regarding wine consumption, the gradual decrease in wine consumption in general is an unquestionable fact today due to new consumer habits and costumes in Spain. Therefore, in the period between 1987 and
2009, there has been a decrease in per capita consumption from 29.96 litres to 16.64 litres of wine in 2009. Meanwhile the per capita consumption of quality wine has shown a more stable tendency. Until 2005 it underwent a progressive increase, after which it began to decline to 6.36 litres per capita in 2009, approximately the same as the consumption in the year 1987 (MAGRAMA, 2012a).

Many factors are responsible for the decrease in wine consumption in Spain. One of the major factors

This is an Open Access article distributed under the terms of the Creative Commons Attribution License (http://creativecommons.org/licenses/by/4.0), which permits unrestricted use, distribution, and reproduction in any medium, provided the original work is properly cited. 
affecting wine consumption, and possibly the most important, is the disappearance of the wine culture in large areas of the country. This is due to consumers shifting towards other drinks, influenced by new lifestyles which promote healthier habits. Consequently, wine, due to its alcohol content and somewhat negative image, is unfavourably viewed by consumers. This negative attitude is motivated by, for example, information campaigns on alcohol intake and increased likelihood of traffic accidents (INTCF, 2015).

The issue here is not whether consumers drink alcohol, since non-consumers are clearly not a major market for wine producers. The problem is rather whether wine consumers are moving, for example, towards the consumption of beer and similar products of lower alcohol content.

At the same time, distributors have made two important mistakes. Firstly, from the point of view of price, the substantial increase in the price of a wine from production to the table, which on occasions is double or triple, has led to rejection by consumers, and encouraged the consumption of other drinks. Secondly, they have failed to identify the characteristics and preferences of the consumers and adapt production accordingly (Bernabéu et al., 2008).

However, wine production has frequently continued to focus on improving vine growing and the winemaking process (which has led to an increase in wine production) and on marketing. Here attention has only really been focused on the variable of advertising while the other variables (product, price and distribution) have been given less importance in the marketing mix. Furthermore, regarding the product, wine consumption preferences have not been evaluated (Bernabéu et al., 2005).

This situation has led to an increase in wine production. Consequently, as a result of the need to sell this increased wine production, and through the use of advertising strategy, there has been a growth in the competitiveness of the different Spanish wineproducing regions. This, in turn, has led to a proliferation of both collective marks (Protected Designations of Origin) and individual brands of wine produced in the different wineries.

This increase in regional competition in wine commercialization has been unequal. Some regions have advanced more rapidly, while others have done so more slowly. This seems to be the case in CastileLa Mancha (Spain), with an extension of 473,050 ha. In 2011 (48\% of the vineyard surface area of Spain) (MAGRAMA, 2012b), it produced 21.46 million hL of wine (approximately $53.8 \%$ of the national production) (JCCM, 2011), but has not shown a relevant presence of its quality wines in national markets (Ikerfel-OeMV, 2012).

In order to determine the market opportunities of the quality wines produced in Castile-La Mancha, it is essential to identify the preferences and socioeconomic characteristics of wine consumers (gender, age, educational level, profession and net monthly family income) in the target markets. It is especially important to evaluate the effect of the origin of the wine on consumer preferences. This is similar to the position of foreign wines targeting the Spanish market.

The origin of wine derives its singularity from a specific geographical location, which provides a unique, sustainable, competitive advantage, truly distinguishable and directly related to the tangible quality of the product, which is difficult to duplicate (Gil and Sánchez, 1997; Thode and Maskulka, 1998). In turn, the place of origin not only assures precise and efficient product identification among the existing diversity, but also contributes to the defence, value added and respect for rural areas (Ribeiro et al., 2002).

The effect of origin in choosing a product can be defined as ethnocentrism (Shimp and Sharma, 1987). Consumer ethnocentrism is an important motivation in the decision to purchase local products. A direct relationship has been found between consumer ethnocentrism and the preference for domestic products, and also a negative relationship to the preference for foreign products (Verlegh and Steenkamp, 1999).

From a functional viewpoint, ethnocentrism confers a sense of identity on an individual, a feeling of belonging, and what seems more important, the understanding of why certain purchasing behaviours are acceptable by the group or not (Witkowsky, 1998).

In this regard, the ethnocentric tendencies of consumers do not only refer to foreign products but also to products from other regions of the country. More ethnocentric consumers think that products from other countries or regions can damage the economy of their own country or region, cause jobs to be lost or even undermine their national or regional identity (Johansson et al., 1985; Wall and Heslop, 1986; Chasin et al., 1988; Han, 1988; Hung, 1989; Sharma et al., 1995; Durvasula et al., 1997; Supphellen and Gronhaug, 2003), however morally incorrect this standpoint might be (Shimp and Sharma, 1987). 
Consumers who exhibit less ethnocentric tendencies base their decisions on the inherent qualities of the product and not the place where it was produced. What is more, on some occasions certain consumers value foreign products more highly than those of their own country or regions, which might also be considered morally incorrect (Bernabéu et al., 2013).

To measure the degree of consumer ethnocentrism, it is necessary to identify a tried-and-tested method. Currently, the most commonly utilised method is the Consumer Ethnocentric Tendency Scale (CETSCALE) (Shimp and Sharma, 1987). This scale measures the tendency of consumers to submit to an ethnocentric purchasing behaviour towards outside products and it has been validated in several studies (Luque-Martinez et al., 2000; Marín, 2005; Chryssochoidis et al., 2007; Kavac and Gumusluoglu, 2007; Parts, 2007).

In order to evaluate the possible commercial success of wines produced in one region and marketed in another, it is necessary to identify the preferences of wine consumers and their socioeconomic and ethnocentric characteristics, in order finally to propose a series of commercial strategies with the purpose of promoting their commercialization. Consequently, a study of the market opportunities of wines from Castile-La Mancha in Madrid and Barcelona was conducted. These are the two most important cities in Spain as consumption and business centres as well as national showcases for wine promotion, while being at the same time different types of wine markets (Bernabéu et al., 2013).

\section{MATERIAL AND METHODS}

In order to identify the structure of the preferences of wine consumers, 800 people over the age of 18 about to buy food products for home consumption were surveyed in supermarkets and hypermarkets in Madrid and Barcelona (Spain) in 2011. Random, stratified sampling was conducted by district population, gender and age group. For a 95.5\% confidence level, under the principle of maximum indetermination, the error level was below $3.54 \%$, as is seen on the technical card on Table I.

Consumer preferences are usually identified using multi-attribute models, which aim to explain how consumers form preferences by evaluating the attributes and levels of a product or service. To detect preferences, it can be said that two models exist (compositional, decompositional) with regard to the analysis techniques used to determine consumer preferences.
Table I

Technical card

Ficha técnica

\begin{tabular}{|c|c|}
\hline Ambit & $\begin{array}{l}\text { Cities of Madrid and } \\
\text { Barcelona (Spain) }\end{array}$ \\
\hline Universe & Adult wine consumers \\
\hline Survey size & $\begin{array}{l}800 \text { surveys ( } 400 \text { in Madrid } \\
\text { and } 400 \text { in Barcelona). }\end{array}$ \\
\hline Survey error & $\pm 3.54 \%$. \\
\hline Level of confidence & $95.5 \%(\mathrm{k}=2)^{\dagger}$ \\
\hline Sampling & $\begin{array}{l}\text { Stratified with proportional } \\
\text { affixation by population } \\
\text { district, gender and age. }\end{array}$ \\
\hline Control & Of coherence and stability. \\
\hline Preliminary questionnaire & Pretest to 25 individuals. \\
\hline Field work & February and March, 2011. \\
\hline
\end{tabular}

In compositional models, those interviewed provide an opinion on several attributes of the same product, estimating its global utility through aggregation. The main criticism levelled at this method is that there are some attributes which consumers do not take into account in their purchasing decisions.

Decompositional models include Conjoint Analysis as a technique to transform consumers' subjective responses into parameters that estimate the utility of each attribute level as declared in their preferences, thus obtaining a measure of consumers' overall satisfaction with the product. The aim of this technique is to help select between products and determine how each attribute impacts on the purchasing process (Green and Rao, 1971). Additionally, these models segment markets in a more precise manner (Wind, 1978).

In this study, in order to identify the most representative attributes in the wine purchasing process of consumers, an advance questionnaire was conducted with consumers and experts (sector professionals and researchers) being interviewed. The literature on the subject was also consulted.

In order to obtain good levels of reliability and validity, the number of attributes was reduced to the four considered most representative of the objectives to be achieved. Furthermore, these attributes were not correlated so as to avoid unreal combinations between levels.

The attributes and their levels identified as most important in quality red wine were: price (4, 6 and 8 $€ / 0.75 \mathrm{~L}$ bottle), type (current year, aged and reserve), origin (local, Castile-La Mancha and national), and 
finally, whether they had previously tasted it (yes, no).

Through these four attributes and their eleven levels, 54 profiles were obtained. This involves a high number of products to show to the consumer. Therefore, an orthogonal design (SPSS Inc., 2009) was used that allowed the combinations to be reduced to nine ${ }^{1}$.

The choice of an orthogonal design compared to the presentation of all the possible combinations of products limits obtainable information only to the main effects of the attributes by eliminating interactions, as interactions tend to explain less than $10 \%$ of preferences. It also offers the advantage of showing only nine products to each respondent. This advantage is thought to outweigh that inconvenience (Kirk, 1982; Braña et al., 1995). The 9 profiles are shown on Table II.

\section{Table II}

Hypothetical wine cards shown to those surveyed

Cartões de preferências do vinho apresentados aos inqueridos

\begin{tabular}{|c|c|c|c|c|}
\hline $\begin{array}{c}\text { Card } \\
\text { number }\end{array}$ & Price $^{\dagger}$ & Origin & Туре & $\begin{array}{c}\text { Tasted } \\
\text { previously }\end{array}$ \\
\hline 1 & 8 & Local Area & Reserve & Yes \\
\hline 2 & 8 & National & Current year & No \\
\hline 3 & 6 & $\begin{array}{l}\text { Castile-La } \\
\text { Mancha }\end{array}$ & Reserve & No \\
\hline 4 & 6 & National & Aging & Yes \\
\hline 5 & 6 & Local Area & Current year & Yes \\
\hline 6 & 4 & National & Reserve & Yes \\
\hline 7 & 4 & $\begin{array}{l}\text { Castile-La } \\
\text { Mancha }\end{array}$ & Current year & Yes \\
\hline 8 & 8 & $\begin{array}{l}\text { Castile-La } \\
\text { Mancha }\end{array}$ & Aging & Yes \\
\hline 9 & 4 & Local Area & Aging & No \\
\hline
\end{tabular}

Once the hypothetical wine cards were designed, they were shown to each of the respondents who assigned a score from 1 to 10 to each card depending on their declared preferences ${ }^{2}$. The object was to discover which characteristics had a greater influence on the overall preference for the wine in question, as well as the relative importance of each attribute.

The specification of the conjoint analysis model is based on the hypothesis that respondent preferences,

\footnotetext{
${ }^{1}$ The number of products evaluated by the consumers was 11 . Nine corresponded to the orthogonal design (those used in calculating the utilities). Two additional products (holdout cases) were for verifying the validity of the utility of the first 9 products (which was not significant). Therefore, they were considered valid (Bernabéu et al., 2012).

${ }^{2}$ The number 1 corresponded to the lowest degree of preference and 10 to the highest, according to the complete profile method. They had the possibility to repeat scores on more than one card.
}

or overall wine valuation, are obtained from the individual scores for each attribute, so that the sum of those scores generates the overall valuation. An additive model was used as the starting point, since in almost every case it explains a very high percentage, between $80 \%$ and $90 \%$, of the variation in individual preferences (Steenkamp, 1987; Hair et al., 1999). Its formula is shown in the following equation:

Valuation $=\beta_{0}+\sum_{i=1}^{3} \beta_{i} D_{1 i}+\sum_{j=1}^{3} \beta_{j} D_{2 j}+\sum_{k=1}^{3} \beta_{k} D_{3 k}+\sum_{l=1}^{2} \beta_{l} D_{4 l}$

where $\beta_{1 i}, \beta_{2 j}, \beta_{3 k}$ and $\beta_{4 l}$ are the coefficients associated to levels i $(\mathrm{i}=1,2,3), \mathrm{j} \quad(\mathrm{j}=1,2,3), \quad \mathrm{k}$ $(\mathrm{k}=1,2,3)$, and $\mathrm{l}(\mathrm{l}=1,2)$ of the attributes of price $(1)$, type (2), origin (3) and tasted previously (4), respectively and where $D_{1 i}, D_{2 j}, D_{3 k}$ and $D_{4 l}$ are the fictitious variables for each attribute, considering the levels of each attribute as categorical.

The final result of the Conjoint program permits estimating the partial utilities of each attribute and the total utility of each profile. Using the partial utilities of each respondent to determine consumer preference structure, the relative importance (RI) of the attributes of each of them was calculated, as well as the proportion of the range assigned to each attribute over the total range variation (Halbrendt et al., 1991; Hair et al., 1999);

$$
R I(\%)=\frac{\max U_{i}-\min U_{i}}{\sum\left(\max U_{i}-\min U_{i}\right)} \times 100
$$

where $R I$, is the relative importance, max $U_{i}$, is the maximum utility and $\min U_{i}$ is the minimum utility.

Subsequently, and on the basis of the relative importance that consumers gave different attributes individually, a multivariate segmentation analysis of K-average conglomerates was made using the Quick Segmentation Analysis (SPSS, 2009) algorithm.

Finally, to detect ethnocentric attitudes in wine consumers from Madrid and Barcelona, the 17 items appearing on the CETSCALE were included in the survey. Consumers were asked to evaluate them from 1 to 7 where 1 was complete disagreement and 7 was complete agreement. Scoring from the scale for each individual may vary between 17 and 119 points $^{3}$. The lowest and the highest values were for the least and the most ethnocentric consumers respectively. Then

\footnotetext{
${ }^{3}$ The internal consistency reliability of the instrument can be measured by Cronbach's alpha. The Cronbach's alpha measure of reliability assumes that items (measured on a Likert-type scale) measuring the same construct will be highly correlated (Welch and Comer, 1988). The closer the alpha value is to 1 , the greater is the internal consistency of the items measured. As a general criterion, George and Mallery (2003) suggest that a Cronbach's alpha of $>0.9$ is excellent. In our case, it is 0.963 .
} 
ethnocentric attitudes of each segment were determined (Shimp and Sharma, 1987).

\section{RESULTS AND DISCUSSION}

In general, wine consumers in Madrid and Barcelona prefer aged wine, of aging and reserve type, and if possible, one they have previously tasted, although consumers from Barcelona are the ones showing greater predisposition to try new wine. What really differentiates consumers from Madrid compared to those from Barcelona is that while the former tend to prefer inexpensive wine from any origin other than from their own region, the latter basically prefer wine elaborated in their own region. This circumstance, in turn, leads to price not playing such an influential role.

The population was segmented according to the relative importance conceded to wine attributes. Three segments of wine consumers were detected with significant differences in each city that differed among themselves in preference structure. In Madrid and Barcelona the first segment grouped wine consumers together who considered the price of the wine as its most important attribute. The second segment included those who considered the origin of the wine as the most important attribute. The third segment particularly valued the type of wine (Table III).

Table III

Utilities assigned to attribute levels

Níveis de utilidades dos atributos

\begin{tabular}{|c|c|c|c|c|c|c|c|c|c|c|c|c|c|c|}
\hline \multirow{3}{*}{$\begin{array}{l}\text { Attributes and } \\
\text { levels }\end{array}$} & \multicolumn{7}{|c|}{ Madrid $(n=400)$} & \multicolumn{7}{|c|}{ Barcelona $(n=400)$} \\
\hline & \multirow{2}{*}{ S.D. } & \multicolumn{2}{|c|}{$\begin{array}{c}\text { Seg. } 1 \\
\text { PRICE } \\
(31.7 \%)^{\dagger}\end{array}$} & \multicolumn{2}{|c|}{$\begin{array}{c}\text { Seg. } 2 \\
\text { ORIGIN } \\
(30.0 \%)^{\dagger}\end{array}$} & \multicolumn{2}{|c|}{$\begin{array}{c}\text { Seg. } 3 \\
\text { TYPE } \\
(38.3 \%)^{\dagger}\end{array}$} & \multirow[t]{2}{*}{ S.D. } & \multicolumn{2}{|c|}{$\begin{array}{c}\text { Seg. 1 } \\
\text { PRICE } \\
(33.4 \%)^{\dagger}\end{array}$} & \multicolumn{2}{|c|}{$\begin{array}{c}\text { Seg. } 2 \\
\text { ORIGIN } \\
(36.7 \%)^{\dagger}\end{array}$} & \multicolumn{2}{|c|}{$\begin{array}{c}\text { Seg. } 3 \\
\text { TYPE } \\
(29.9 \%)^{\dagger}\end{array}$} \\
\hline & & $\begin{array}{l}\text { RI } \\
(\%)\end{array}$ & & $\begin{array}{l}\text { RI } \\
(\%)\end{array}$ & U & $\begin{array}{l}\text { RI } \\
(\%)\end{array}$ & U & & $\begin{array}{l}\mathrm{RI} \\
(\%)\end{array}$ & U & $\begin{array}{l}\text { RI } \\
(\%)\end{array}$ & U & $\begin{array}{l}\mathrm{RI} \\
(\%)\end{array}$ & $\mathrm{U}$ \\
\hline Price & ** & 74.01 & & 10.47 & & 16.63 & & & 56.86 & & 15.64 & & 35.15 & \\
\hline $4 €$ & $* *$ & & 2.14 & & -0.11 & & 0.39 & $* *$ & & -0.66 & & 0.28 & & 0.87 \\
\hline $6 €$ & $* *$ & & -0.17 & & 0.24 & & 0.06 & $* *$ & & 0.16 & & -0.13 & & 0.06 \\
\hline $8 €$ & $* *$ & & -1.97 & & -0.13 & & -0.45 & $* *$ & & 0.50 & & -0.15 & & -0.93 \\
\hline Origin & $* *$ & 9.93 & & 60.47 & & 8.32 & & $* *$ & 7.84 & & 57.09 & & 8.01 & \\
\hline Castile-La Mancha & $* *$ & & 0.22 & & 0.87 & & 0.16 & $* *$ & & 0.08 & & -0.84 & & -0.05 \\
\hline Local Area & $* *$ & & -0.33 & & -1.21 & & -0.26 & $* *$ & & 0.00 & & 0.73 & & 0.23 \\
\hline National & * & & 0.11 & & 0.34 & & 0.10 & $* *$ & & -0.08 & & 0.11 & & -0.18 \\
\hline Type & ** & 9.93 & & 12.21 & & 65.15 & & $* *$ & 13.73 & & 26.54 & & 50.98 & \\
\hline Current year & $* *$ & & -0.35 & & -0.18 & & -1.91 & $* *$ & & -0.10 & & -0.28 & & -1.65 \\
\hline Aging & $* *$ & & 0.20 & & 0.24 & & 0.53 & $* *$ & & -0.08 & & -0.17 & & 0.69 \\
\hline Reserve & $* *$ & & 0.15 & & -0.06 & & 1.38 & $* *$ & & 0.18 & & 0.45 & & 0.96 \\
\hline Tastedpreviously & ** & 6.13 & & 16.85 & & 9.90 & & $* *$ & 21.57 & & 0.73 & & 5.86 & \\
\hline Yes & & & 0.17 & & 0.29 & & 0.25 & $* *$ & & 0.22 & & -0.01 & & 0.15 \\
\hline No & & & -0.17 & & -0.29 & & -0.25 & $* *$ & & -0.22 & & 0.01 & & -0.15 \\
\hline
\end{tabular}

Considering significant differences in attributes by segments in Madrid, it was found that regarding price, wine consumers from the first segment were those who valued low prices the most (up to $4 €$ for a $3 / 4$ litre bottle). Consumers from the second segment were those who valued high prices ( $6 €$ per $3 / 4$ litre bottle), perhaps because they might have a behaviour of judging quality by the price.

Regarding the origin attribute, consumers from the second segment were those who valued the wine origin the most of all three segments: positively (those from Castile-La Mancha and national wines) as well as negatively (those from their own region). Lastly, regarding the type attribute, consumers from the third segment were the ones who valued aged wine the most (aging and reserve) while those from the second segment were the ones who most valued young wine or wine from the current year.

Considering significant differences in attributes by segments in Barcelona, it was found that regarding price, wine consumers from the third segment were the ones who valued low prices the most (up to $4 €$ per $3 / 4$ litre bottle). Consumers from the first segment 
were the ones who valued high prices the most (6€ per $3 / 4$ litre bottle).

Regarding the origin attribute, consumers from the second segment were those who valued the origin of the wine the most, positively (those from their own region and national wine) as well as negatively (those from Castile-La Mancha). Lastly, regarding the type attribute, consumers from the third segment were the ones who valued aged wines the most (aging and reserve) while those from the first segment were the ones who valued young wines or those from the current year the most.

Considering significant differences from comparing wine consumer segments from Madrid to those from Barcelona, with a $1 \%$ maximum level of error, it was found that regarding price, consumers from Madrid chose less expensive wines than those from Barcelona. Regarding origin, wine consumers from Madrid preferred wines whose origin was different from those of their own region and preferred those from Castile-La Mancha. Consumers from Barcelona preferred wine from their own region, and in any case, national wine other than those from Castile-La Mancha. Lastly, regarding the type, wine consumers from Madrid as well as those from Barcelona preferred aged wines, although those from Barcelona were the ones who preferred them aged longer.

The socioeconomic characteristics of consumer segments depending on their preferences in wine consumption are shown on Table IV.

Table IV

Socio-economic characteristics of consumer segments (\%)

Características socioeconómicas dos segmentos de consumidores (\%)

\begin{tabular}{|c|c|c|c|c|c|c|c|c|}
\hline \multirow[b]{2}{*}{ Variables } & \multicolumn{6}{|c|}{ Madrid $(n=400)$} & \multicolumn{2}{|c|}{ Barcelona $(n=400)$} \\
\hline & S.D. & $\begin{array}{l}\text { Seg. } 1 \\
\text { PRICE }\end{array}$ & $\begin{array}{c}\text { Seg. } 2 \\
\text { ORIGIN }\end{array}$ & $\begin{array}{l}\text { Seg. } 3 \\
\text { TYPE }\end{array}$ & S.D. & $\begin{array}{l}\text { Seg. } 1 \\
\text { PRICE }\end{array}$ & $\begin{array}{c}\text { Seg. } 2 \\
\text { ORIGIN }\end{array}$ & $\begin{array}{l}\text { Seg. } 3 \\
\text { TYPE }\end{array}$ \\
\hline \multicolumn{9}{|l|}{ Gender } \\
\hline Male & & 43.4 & 45.2 & 53.1 & & 53.0 & 43.4 & 45.8 \\
\hline Female & & 56.6 & 54.8 & 46.9 & & 47.0 & 56.6 & 54.2 \\
\hline Age (in years) & & & & & ** & & & \\
\hline $18-24$ & & 11.5 & 7.0 & 11.6 & & 9.8 & 2.7 & 6.8 \\
\hline $25-34$ & & 18.9 & 22.6 & 19.0 & & 25.8 & 15.9 & 23.7 \\
\hline $35-49$ & & 24.6 & 35.7 & 27.9 & & 23.5 & 28.3 & 30.5 \\
\hline $50-64$ & & 18.9 & 19.1 & 23.1 & & 18.9 & 24.8 & 20.3 \\
\hline$\geq 65$ & & 26.2 & 15.7 & 18.4 & & 22.0 & 28.3 & 18.7 \\
\hline Education & ** & & & & & & & \\
\hline Grade School & & 45.9 & 20.0 & 24.5 & & 25.7 & 30.4 & 22.9 \\
\hline High School & & 24.6 & 37.4 & 38.1 & & 45.5 & 37.9 & 49.1 \\
\hline College & & 29.5 & 42.6 & 37.4 & & 28.8 & 31.7 & 28.0 \\
\hline \multicolumn{9}{|l|}{ Work role } \\
\hline Housewife & & 14.8 & 10.4 & 8.8 & & 6.8 & 8.3 & 7.6 \\
\hline Employee & & 36.8 & 47.0 & 51.0 & & 49.2 & 52.4 & 46.6 \\
\hline Student & & 11.5 & 7.8 & 8.2 & & 3.0 & 1.4 & 8.5 \\
\hline Businessman & & 2.5 & 11.3 & 4.8 & & 11.4 & 10.3 & 10.2 \\
\hline Retired & & 27.0 & 16.5 & 19.7 & & 16.7 & 22.1 & 15.2 \\
\hline Other & & 7.4 & 7.0 & 7.5 & & 12.9 & 5.5 & 11.9 \\
\hline Monthly family net income (€) & $* *$ & & & & & & & \\
\hline$<900$ & & 16.4 & 9.6 & 8.8 & & 9.1 & 9.7 & 10.1 \\
\hline 900 to $<1,500$ & & 27.0 & 22.6 & 23.8 & & 25.7 & 31.0 & 24.6 \\
\hline 1,500 to $<2,100$ & & 33.6 & 19.1 & 31.3 & & 25.8 & 24.8 & 33.9 \\
\hline 2,100 to $<3,000$ & & 16.4 & 29.6 & 23.8 & & 25.8 & 22.8 & 24.6 \\
\hline$>3,000$ & & 6.6 & 19.1 & 12.2 & & 13.6 & 11.7 & 6.8 \\
\hline
\end{tabular}

In Madrid, a significant relation is noticed between the wine chosen and the level of education and net monthly family income. In this sense, consumers who chose wine for its price frequently had a primary education. Those who chose it for the type of wine had a secondary education and those who did it for the origin of the wine, a higher education. This was corroborated with net monthly family income, because segment 1 is the one that has a lower average income and chooses by price. Segment 3 , having a higher income, chooses by the type of wine. Segment
2 has the highest income and chooses by the origin of the wine, perhaps due to the presence in this segment of a higher percentage of businesspeople.

In Barcelona, the only significant relation to the wine chosen regarded age, so that the youngest wine consumers (segment 1 ) chose it for its price, the medium aged consumers (segment 3), for the type of wine and lastly, older consumers, for its origin (segment 2). The latter, but without significant 
differences, were also the ones who had a higher educational level.

Additionally and as a complement to the socioeconomic characteristics of the wine consumer segments, it was proposed to determine whether the effect of origin in the choice of a wine was due to consumer ethnocentrism as defined in the methodology by Shimp and Sharma (1987): the preference of products from one's own region in detriment to those from other regions (Table V).

Table V

Average values from the CETSCALE variables

Valores médios das variáveis CETSCALE

\begin{tabular}{|c|c|c|c|c|c|c|c|c|}
\hline \multirow[b]{2}{*}{ Variables } & \multicolumn{4}{|c|}{ Madrid } & \multicolumn{4}{|c|}{ Barcelona } \\
\hline & S.D. & $\begin{array}{l}\text { Seg. } 1 \\
\text { PRICE }\end{array}$ & $\begin{array}{r}\text { Seg. } 2 \\
\text { ORIGIN }\end{array}$ & $\begin{array}{l}\text { Seg. } 3 \\
\text { TYPE }\end{array}$ & S.D. & $\begin{array}{l}\text { Seg. } 1 \\
\text { PRICE }\end{array}$ & $\begin{array}{c}\text { Seg. } 2 \\
\text { ORIGIN }\end{array}$ & $\begin{array}{l}\text { Seg. } 3 \\
\text { TYPE }\end{array}$ \\
\hline $\begin{array}{l}\text { 1. }[\dagger] \text { consumers should always buy } \\
\text { products... }\end{array}$ & & 2.31 & 2.23 & 2.20 & & 2.73 & 2.86 & 2.51 \\
\hline $\begin{array}{l}\text { 2. Only those products that are not available in } \\
{[\dagger] \text { should be imported... }}\end{array}$ & & 2.19 & 2.17 & 2.48 & & 2.89 & 2.83 & 2.53 \\
\hline $\begin{array}{l}\text { 3. Buying products from }[\dagger] \text { means saving } \\
\text { jobs in our region... }\end{array}$ & & 3.34 & 3.26 & 3.14 & & 3.41 & 3.51 & 3.19 \\
\hline $\begin{array}{l}\text { 4. }[\dagger] \text { products should be considered as the } \\
\text { first, last and most important... }\end{array}$ & & 2,02 & 2.45 & 2.27 & & 2.98 & 2.97 & 2.63 \\
\hline $\begin{array}{l}\text { 5. Purchasing products made outside the } \\
\text { region is anti-[†]... }\end{array}$ & & 1.71 & 1.51 & 1.69 & $* *$ & 2.15 & 2.47 & 1.71 \\
\hline $\begin{array}{l}\text { 6. It is not good to purchase products made } \\
\text { outside the region because... }\end{array}$ & & 2.27 & 2.02 & 2.22 & $* *$ & 2.58 & 2.56 & 2.03 \\
\hline $\begin{array}{l}\text { 7. A true }[\dagger] \text { consumer should always buy } \\
\text { products made in }[\dagger] . .\end{array}$ & & 1.97 & 1.99 & 1.96 & & 2.42 & 2.46 & 2.13 \\
\hline $\begin{array}{l}\text { 8. We should purchase products made in }[\dagger] \\
\text { instead of allowing other... }\end{array}$ & & 2.22 & 1.95 & 2.03 & $* *$ & 2.46 & 2.68 & 2.04 \\
\hline $\begin{array}{l}\text { 9. It is best always to purchase products made } \\
\text { in }[\dagger] . .\end{array}$ & & 2.05 & 1.97 & 2.16 & * & 2.56 & 2.83 & 2.36 \\
\hline $\begin{array}{l}\text { 10. There should be very little commerce or } \\
\text { acquisition of goods... }\end{array}$ & & 2.01 & 1.97 & 2.14 & * & 2.60 & 2.76 & 2.27 \\
\hline $\begin{array}{l}\text { 11. [ } \dagger] \text { consumers should not purchase } \\
\text { products from other areas... }\end{array}$ & & 2.23 & 1.91 & 2.28 & $* *$ & 2.50 & 2.66 & 1.97 \\
\hline 12. All imports should be curbed... & & 1.89 & 1.69 & 2.01 & $* *$ & 2.32 & 2.32 & 1.81 \\
\hline $\begin{array}{l}\text { 13.It may cost me more in the long run but I } \\
\text { prefer to support }[\dagger] \text { products... }\end{array}$ & $*$ & 3.63 & 3.30 & 3.04 & & 3.15 & 3.34 & 3.15 \\
\hline $\begin{array}{l}\text { 14. People from other regions should not be } \\
\text { authorized to place their products. }\end{array}$ & & 2.25 & 2.40 & 2.35 & * & 2.40 & 2.63 & 2.18 \\
\hline $\begin{array}{l}\text { 15. Products from other regions should be } \\
\text { heavily taxed to reduce their... }\end{array}$ & & 2.38 & 2.66 & 2.54 & & 2.86 & 2.84 & 2.58 \\
\hline $\begin{array}{l}\text { 16. We should only purchase from other areas } \\
\text { those products that... }\end{array}$ & & 2.57 & 2.56 & 2.56 & & 2.88 & 3.00 & 2.65 \\
\hline $\begin{array}{l}\text { 17. }[\dagger] \text { consumers who purchase products } \\
\text { made in other regions... }\end{array}$ & & 1.93 & 1.83 & 2.12 & $* *$ & 2.27 & 2.39 & 1.86 \\
\hline TOTAL & & 38.96 & 37.85 & 39.18 & & 45.16 & 47.11 & 39.60 \\
\hline
\end{tabular}

In general, consumers from Madrid and Barcelona did not show a clear ethnocentric behaviour regarding the products elaborated in their region since the values obtained on the CETSCALE were below the half-way point in the scores of the scale (68 points). Nevertheless, consumers from Barcelona are more ethnocentric than consumers from Madrid.

Wine consumers from Madrid as well as those from Barcelona chose wine for its origin. The former were less ethnocentric, searching for the more inexpensive wine. The latter looked basically for wine from their region. Comparing both consumer segments, from Madrid and from Barcelona, significant differences appear regarding origin, with a $1 \%$ maximum level of error in items $5,8,9,10,11$, and 12 , and with a $5 \%$ maximum level of error in items 1, 2, 4, 6, 7, and 17. Therefore, it was verified that wine consumers from Barcelona are more ethnocentric than consumers from Madrid.

To end this section, it must be pointed out that the consistency of the results derived from the Conjoint Analysis technique and those obtained by using the CETSCALE, reinforce and complement one another.

Some authors find that consumers indicate low price as a clear reason for their choice of wine (Albiac et al., 1986). Meanwhile, others find that consumers select wine according to the region of origin, assuming that wine derives its singularity from a specific geographical location. These authors indicate 
that origin can provide producers with a sustainable competitive advantage since it is unique, truly differentiable and directly connected to the tangible quality of the product (Thode and Maskulka, 1998). Moreover, origin can override preferences for low prices.

In fact, in various papers the area of origin has shown its importance in consumer wine choice (Gil and Sánchez, 1997; Skuras and Vakrou, 2002; MartinezCarrasco et al., 2006). Nevertheless, Loureiro (2003) found that consumers willing to pay more for wine labelled with the Colorado (USA) origin, would pay only a little more for it and concluded that what is really important is to establish a good reputation for quality.

Shimp and Sharma (1987) carried out an early study in which they analysed the effect of ethnocentrism on the choice of a product. They defined it as "beliefs held by consumers about the appropriateness or morality of purchasing foreign products" since the purchase of foreign products harms the domestic economy and causes job losses.

Therefore, non-ethnocentric consumers evaluated products on their own merits without considering where they were made. Shimp and Sharma (1987) indicate that consumer ethnocentrism moderately predicts consumer beliefs, attitudes and purchasing intentions as well as their level of purchasing. Several authors establish that consumer ethnocentrism is one of the aspects that helps predict consumer judgements about the quality of acquired products (Netemeyer et al., 1991; Sharma et al., 1995).

It must be pointed out that CETSCALE scores were low in both of the markets under analysis (39.18 for the most ethnocentric segment from Madrid and 47.11 for the most ethnocentric segment from Barcelona), especially when compared to similar studies conducted in our country: 65.29 in the Community of Valencia (Brugarolas et al., 2009) and 70.87 in the province of Valencia (Marín, 2005).

This difference could be due to the fact that research by Marín and Brugarolas et al. was carried out in

\section{REFERENCES}

Albiac J., Albisu L.M., Alejandre J.L., 1986. Actitud de los consumidores respecto al vino. MAPA: Serie Economía, 31.

Bernabéu R., Brugarolas M., Martínez-Carrasco L., Díaz M., 2008. Wine origin and organic elaboration, differentiating strategies in traditional producing countries. Brit. Food J., 110 (2), 174-188.

Bernabéu R., Olmeda M., Díaz M., 2005. Estructura de preferencias de los consumidores de vino y actitudes hacia los wider territories that included both large and small population nuclei, while the study described here was conducted in the two most populated Spanish cities.

\section{CONCLUSIONS}

According to the preferences declared by wine consumers, in Madrid the most preferred wine was the lowest priced one, in Barcelona the most preferred was the one originating in their own region. In this sense, it is significant that while wines produced in Madrid region are the least preferred by Madrid consumers, wines produced in Catalonia are the most preferred by consumers from Barcelona.

From the analysis of wine consumer preferences, from their socioeconomic characteristics and degree of ethnocentrism, it seems to follow that there are commercial opportunities in the Madrid market for wine elaborated in Castile-La Mancha. Given its production structure, it can compete generically at low prices. Although it can also compete at medium prices for those consumers who prefer wine for its origin, who in turn are the ones who have greater purchasing power.

In Barcelona, market opportunities for Castile-La Mancha wines are scarce since, either they are unfamiliar or they are simply not preferred. To overcome that unfamiliarity with Castile-La Mancha wines there is no other solution than to conduct several communication strategies, jointly and mutually shared by the designations of origin, in favour of the wines produced in Castile-La Mancha, and by the wineries individually, to offer aged wine at reasonable prices with the object of attracting the most innovative wine consumers.

Finally, future lines of research should specifically include wines from other countries in the markets of Madrid and Barcelona, determining their level of acceptance among consumers in these markets, drawing on the structure of their preferences and their degree of ethnocentrism.

vinos con Denominación de Origen. El caso de Castilla-La Mancha. Economía Agraria y Recursos Naturales, 5, 57-80.

Bernabéu R., Prieto A., Díaz M., 2013. Preference patterns for wine consumption in Spain depending on the degree of consumer ethnocentrism. Food Qual. Prefer., 28 (1), 77-84.

Bernabéu R., Tendero A., Olmeda M., 2012. Consumer preferences versus commercial differentiation: A Spanish case study. Brit. Food J., 114 (11), 1626-1639. 
Braña T., Ferraces M.J., Varela J., 1995. Diseño factorial incompleto. IV Simposium de Metodología de las Ciencias del Comportamiento. Murcia (Spain).

Brugarolas M., Martínez-Poveda A., Martínez-Carrasco L., 2009. Aceptación de productos en los mercados locales: El aceite de oliva en la Comunidad Valenciana, VII Congreso Nacional de Economía Agraria. Almería (Spain).

Chasin J., Holzmuller H., Jaffe E., 1988. Stereotyping, buyer familiarity and ethnocentrism: a cross-cultural analysis. J. Int. Consum. Market., 1 (2), 9-29.

Chryssochoidis G., Krystallis A., Perreas P., 2007. Ethnocentric beliefs and country-of-origin (COO) effect: Impact of country, product and product attributes on Greek consumers' evaluation of food products. Eur. J. Marketing, 41 (11/12), 1518-1544.

Durvasula S., Andrews C., Netemeyer R., 1997. A cross-cultural comparison of consumer ethnocentrism in the United States and Russian. J. Int. Consum. Market., 9 (4), 73-84.

George D., Mallery P., 2003. SPSS for Windows step by step: A simple guide and reference. 11.0 update (4th ed.). Boston: Allyn \& Bacon, 386 pp.

Gil J.M., Sánchez M., 1997. Consumer preferences for wine attributes. A Conjoint approach. British Food Journal, 99 (1), 3-11.

Green P.E., Rao V.R., 1971. Conjoint Measurement from Quantifying Judgemental Data. J. Marketing Res., 8, 355-363.

Hair J.F., Anderson R.E., Tatham R.L., Black W.C., 1999. Análisis multivariante. Prentice-Hall. Madrid (Spain), 799 pp.

Halbrendt C.K., Wirth E.F., Vaughn G.F., 1991. Conjoint analysis of the Mid-Atlantic food-fish market for farm-raised hybrid stripted bass. Southtern Journal of Agricultural Economics, July, 155-163.

Han C., 1988. The role of consumer patriotism in the choice of domestic versus foreign products. J. Advertising Res., June-July, 25-32.

Hung C., 1989. A country of origin product image study: The Canadian perception and nationality biases. J. Int. Consum. Market., 1, 5-26.

Ikerfel-OeMv, 2012. Estudio entorno al consumo de vino en la población española: frenos al consumo y potenciales aceleradores del consumo de vino. Available at: http://www.oemv.es/esp/estudio-oemv-consumo-de-vino-en-lapoblacion-espanola-frenos-al-consumo-y-potenciales-aceleradoresdel-consumo-responsable-de-vino-682k.php (Accessed 29 Dec 2014).

Instituto Nacional de Toxicología y Ciencias Forenses (INTCF), 2015. Memoria 2014. Available at: https://www.administraciondejusticia.gob.es/paj/PA_WebApp_SG NTJ_NPAJ/descarga/Memoria\%20Tr\%C3\%A1fico\%20INTCF\%2 02014.pdf?idFile=00359cf9-26d5-4d33-96ea-ec9703c78470 (Accessed 18 Dec 2016).

Johansson J.K., Douglas S.P., Nonaka I., 1985. Assessing the impact of country of origin on product evaluations: a new methodological perspective. J. Marketing Res., 22, 388-396.

Junta de Comunidades de Castile-La Mancha (JCCM), 2011. Estrategia regional del vino. Available at: http://www.jccm.es/web/es/CastillaLaMancha/index/plan

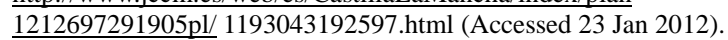

Kavak B., Gumusluoglu L., 2007. Segmenting food markets: The role of ethnocentrism and lifestyle in understanding purchasing intentions. Int. J. Market Res., 49 (1), 71-94.
Kirk J., 1982. Experimental design: Procedures for the behavioural sciences. Brooks-Cole Co. $2^{\text {nd }}$ ed. Monterrey, CA, 500 pp.

Loureiro M.L., 2003. Rethinking new wines: implications of local and environmentally friendly labels. Food Policy, 28, 547-560.

Luque-Martínez T., Ibáñez-Zapata J.A., Del Barrio-García S., 2000. Consumer etnocentrism measurement An assessment of the reliability and validity of the CETSCALE in Spain. Eur. $J$. Marketing, 34 (11/12), 1353-1373.

Marín S.C., 2005. El origen doméstico de los productos como ventaja competitiva: La etnocentricidad del consumidor. Universitat de Valencia. Valencia (Spain).

Martínez-Carrasco L., Brugarolas M., Del Campo F.J., Martínez A., 2006. Influence of purchase place and consumption frequency over quality wine preferences. Food Qual. Prefer., 17, 315-327.

Ministerio de Agricultura, Alimentación y Medio Ambiente (MAGRAMA), (2012a). Panel de consumo alimentario. Available at: $\quad$ http://www.marm.es/es/alimentacion/temas/consumo-ycomercializacion-y-distribucion-alimentaria/ (Accessed 2 Mar 2012).

Ministerio de Agricultura, Alimentación y Medio Ambiente (MAGRAMA), (2012b). Encuesta sobre superficies y rendimientos de cultivo (ESYRCE). Available at: http://www.marm.es/es/estadistica/temas/default.aspx (Accessed 19 Jan 2012).

Netemeyer R., Durvasula S., Lichtenstein D., 1991. A crossnational assessment of the reliability and validity of the CETSCALE. J. Marketing Res., 28, 320-327.

Parts O., 2007. The measurement of consumer ethnocentrism and COO effect in consumer research. Transform. Bus. Econ., 6 (1), 139-154.

Ribeiro A., Melo A.C., Vilhena R., 2002. Appellation of origin/geographical indication a strategy for the new vitivinicultural world. Paper presented at XXVII World Congress on Vine and Wine. Bratislava (Slovakia).

Sharma S., Shimp T., Shin J., 1995. Consumer Ethnocentrism: A test of antecedents and moderators. J. Acad. Market. Sci., 23 (1), 26-37.

Shimp T., Sharma S., 1987. Consumer Ethnocentrism: Construction and Validation of the CETSCALE. J. Marketing Res., 24, 280-289.

Skuras D., Vakrou A., 2002. Consumer's willingness to pay for origin labelled wine: A Greek case study. Brit. Food J., 104 (11), 898-912.

\section{SPSS Inc., 2009. SPSS Categories. Version 15.0. Chicago}

Steenkamp J.B., 1987. Conjoint measurement in ham quality evaluation. J. Agr. Econ., 38, 473-480.

Supphellen M., Gronhaug K., 2003. Building foreign brand personalities in Russia: the moderating effect of consumer ethnocentrism. Int. J. Advert., 22, 203-226.

Thode S.F., Maskulka J.M., 1998. Place-based marketing strategies, brand equity and vineyard valuation. Journal of Product \& Brand Management, 7 (5), 379-399.

Verlegh P.W.J., Steenkamp J.B.E.M., 1999. A review and metaanalysis of country-of-origin research. J. Econ. Psychol., 20, 521546.

Wall P., Heslop L.A., 1986. Consumer attitudes toward Canadianmade versus imported product. J. Acad. Market. Sci., 8 (4), 345356. 
Welch S., Comer J.C., 1988. Quantitative methods for public administration: techniques and applications. Chicago: Dorsey Press, $362 \mathrm{pp}$.

Wind Y., 1978. Issues and advances in segmentation research. $J$. Marketing Res., 15, 317-337.
Witkowsky T., 1998. Consumer ethnocentrism in two emergent markets: determinants and predictive validity. Adv. Consum. Res., 25, 258-263. 